\title{
DNA Interstrand Cross-Link Repair
}

National Cancer Institute

\section{Source}

National Cancer Institute. DNA Interstrand Cross-Link Repair. NCI Thesaurus. Code C20225.

DNA interstrand cross-links (ICLS) are very toxic to dividing cells, because they induce mutations, chromosomal rearrangements and cell death. A number of multi-step DNA repair pathways including nucleotide excision repair, homologous recombination and post-replication/translesion repair all impinge on their repair. 